\title{
Bankacılıkta Müşteri Deneyimine Yönelik Bibliyometrik Analiz: 1991-2020 Dönemine Ait Temaların ve İlişki Ağlarının Belirlenmesi \\ (Bibliometric Analysis of Customer Experience in Banking: Determining The Themes and Relationship Networks of the Period 1991-2020)
}

\author{
Gülsen ALKAÇ ÖZDEMİR iD a Murat Hakan ALTINTAŞ iD b \\ a Bursa Uludağ Üniversitesi, Sosyal Bilimler Meslek Yüksekokulu, Bursa, Türkiye.gulsenozdemir@uludag.edu.tr \\ • Bursa Uludağ Üniversitesi, İktisadi ve İdari Bilimler Fakültesi, İşletme Bölümü, Bursa, Türkiye. mhakan@uludag.edu.tr
}

\begin{tabular}{|c|c|}
\hline MAKALE BİLGİSİ & ZET \\
\hline $\begin{array}{l}\text { Anahtar Kelimeler: } \\
\text { Müşteri Deneyimi } \\
\text { Bankacılık } \\
\text { Bankacilıkta Müşteri Deneyimi } \\
\text { Bibliyometrik Analiz } \\
\text { Vosviewer }\end{array}$ & $\begin{array}{l}\text { Amaç - Bu çalışmanın amacı, bankacılıkta müşteri deneyimi konusunda son } 30 \text { yıl içerisinde yapılan } \\
\text { çalışmaları bibliyometrik analiz yöntemiyle inceleyerek, bankacılıkta müşteri deneyimine ilişkin } \\
\text { kelime bazlı kümeleri ve bu kümelerin alt unsurlarını, ele alınan ana temaları ve oluşan ilişki ağlarını } \\
\text { belirlemektir. } \\
\text { Yöntem - Bibliyometrik analiz için gerekli veriler, 29-30 Mart } 2021 \text { tarihlerinde WOS veri tabanından } \\
\text { "customer experience - banking" anahtar kelimesi seçilerek elde edilmiştir. Bibliyometrik analiz, 1991- } \\
2020 \text { yıllarını kapsayan dönemde WOS veri tabanında yer alan ve ilgili anahtar kelimeler girilerek } \\
\text { elde edilen } 293 \text { makale üzerinden gerçekleştirilmiştir. Bibliyometrik analiz eş-oluşum yöntemiyle } \\
\text { gerçekleştirilmiş ve analiz için çalışmada Vosviewer programı kullanılmışıtır. } \\
\text { Bulgular - Gerçekleştirilen bibliyometrik analiz sonucunda, makale sayısının özellikle } 2016 \text { yılı ve } \\
\text { sonrasında dramatik olarak arttığ1, makalelerin yayınlandığ1 dergilerin ağırlıklı olarak işletme ve } \\
\text { ekonomi alanında yoğunlaştığı bulunmuştur. Ayrıca ilgili anahtar kelime kapsamında } 40 \text { alt unsura } \\
\text { sahip } 8 \text { küme ve kelime bazlı ilişki ağları tespit edilmiştir. Bulunan kümeler sırasıyla; müşteri adaleti } \\
\text { ve koruma, teknoloji adaptasyonu, değer odaklı bağllık, deneyimi hissetme, hizmeti alglama, marka } \\
\text { odaklılık, hizmet iklimi ve müşteri yapisı olarak isimlendirilmiştir. Müşteri deneyimi odaklı olarak ağ } \\
\text { ilişkileri analiz edildiğinde ise, bankacılık sektörü, müşteri sayısını koruma, müşteri memnuniyeti, } \\
\text { ilişki kalitesi, hizmet kalitesi, müşteri değeri, WOM gibi konuların ilişki ağında öne çıkan konular } \\
\text { olduğu bulunmuştur. } \\
\text { Tartışma - Günümüzün yoğun rekabet ortamında, müşteri kazanmak ve uzun vadede elde tutmak } \\
\text { her banka için önemlidir. Sürdürülebilir rekabetçi avantaja sahip olmak için bankalar, müşteri } \\
\text { deneyimini yönetmek ve bu noktada farklılaşarak öne çıkmak zorundadırlar. Bu çalışma teorik açıdan } \\
\text { bankacılık sektöründe müşteri deneyiminin gelişim yönünü, pratik açıdan ise bankaların yönelmesi } \\
\text { gereken konuları ortaya koyması açısından önemli sonuçlara sahiptir. }\end{array}$ \\
\hline
\end{tabular}

ARTICLE INFO

Keywords:

Customer Experience

Banking

Customer Experience in

Banking

Bibliometric Analysis

Vosviewer

Received 3 November 2020

Revised 20 June 2021

Accepted 25 June 2021

Article Classification:

Research Article

\section{ABSTRACT}

Purpose - This study aims to examine the studies on customer experience in banking with the bibliometric analysis method and determine the word-based clusters and their members, the main themes discussed, and the network of relationships formed regarding the customer experience in banking.

Design/methodology/approach - The data required for bibliometric analysis were obtained by selecting the keyword "customer experience - banking" from the WOS database on March 29-30, 2021. The bibliometric analysis was carried out over 293 articles in the WOS database, obtained by entering relevant keywords in the period 1991-2020. Bibliometric analysis was carried out with the cooccurrence method, and the Vosviewer program was used in the study for analysis.

Findings - As a result of the bibliometric analysis, it was found that the number of articles increased dramatically, especially in 2016 and after, and the journals in which the articles were published mainly concentrated on business and economics. Also, 8 clusters with 40 sub-elements within the relevant keyword's scope and word-based relationship networks were determined. These clusters found are respectively; customer justice and retention, technology adaptation, value-oriented commitment, sense of experience, service perception, brand orientation, service climate and customer structure. When the network relations are analyzed with a focus on customer experience, it is found that the

\section{Önerilen Atıf/ Suggested Citation}

Alkaç Özdemir, G., Altıntaş, M. H. (2021). Bankacılıkta Müşteri Deneyimine Yönelik Bibliyometrik Analiz: 1991-2020 Dönemine Ait Temaların ve İlişki Ağlarının Belirlenmesi, İşletme Araştırmaları Dergisi, 13 (2), 1856-1871. 
banking sector, customer retention, customer satisfaction, relationship quality, service quality, customer value, WOM are prominent issues in the relationship network.

Discussion - In today's intensive competitive environment, gaining customers and retaining them in the long term is vital for every bank. To have a sustainable competitive advantage, banks have to manage the customer experience and stand out by differentiating at this point. This study has important results in revealing the development aspect of the customer experience in the banking sector from a theoretical perspective and the issues that banks should focus on in practical terms.

\section{GİRIŞ}

Müşterilerin kesintisiz ve kişiselleştirilmiş bankacılık hizmetleri talebi ve teknolojik gelişmeler nedeniyle bankacılık sektörü hızlı ve geniş çaplı değişimler yaşamaktadır (Komulainen ve Makkonen, 2018). Bankacılıkta müşteri deneyimi, müşterinin çok sayıda temas noktasıyla karşılaşması sonucunda bankayla karşılaştığı tüm etkileşimlerin etkisini ifade etmektedir (Handro, 2017). Bankacılık sektöründe müşterilerle kaliteli ilişkiler geliştirmek büyük önem taşımaktadır (Fernandes ve Pinto, 2019). Üstün müşteri deneyimi yaratmak, işletmelerin temel hedeflerinden biridir. Dünyanın dört bir yanındaki işletmeler, müşteri deneyim yönetimi kavramını benimsemiş ve birçoğu bu kavramı misyon ifadelerine yerleştirmiştir (Verhoef vd., 2009: 31). Bu davranışın temel vurgusu aslında müşteri deneyiminin, rekabet avantajı ve ticari başarının önemli bir itici gücü olmasından kaynaklanmaktadır (Lemon ve Verhoef, 2016).

Uygulayıcılar açısından müşteri deneyiminin öneminin kabul edilmesiyle birlikte müşteri deneyimi konusu özellikle 2000'li yılların başında uygulamaya yönelik yayınlarda kendisine yer bulmuştur. Bu konuda yayınlanan çeşitli kitaplarda (Shaw ve Ivens, 2002; Shaw, 2005; 2007; Tisch ve Weber, 2007; DiJulius, 2008) ve uygulamaya yönelik dergilerde (Berry vd., 2002; Meyer ve Schwager, 2007) müşteri deneyimi konusu ele alınmıştır. 2000'li yıllardan önce sınırlı olan müşteri deneyimiyle ilgili akademik pazarlama literatürü, 2000'li yıllarla birlikte genişlemeye başlamış ve çeşitli bağlamlarda müşteri deneyimi konusu nitel ve nicel çalışmalarda incelenmiştir.

Bankacılık sektörü, müşteri deneyiminin araştırıldığı önemli alanlardan biridir. Bankacılık sektöründe yapılan çalışmaların önemli bir kısmı bireysel bankacılık alanıyla (Özturkcan Aykaç \& de Kervenoael, 2008; Drotskie, 2009; Ater ve Landsman, 2013; Chandok ve Gupta, 2013; Handro, 2018; Fernandes ve Pinto, 2019; Kumar, 2020; Marangoz \& Erboy, 2020) ilgili iken, diğer bir kısmı da dijital ve çevrimiçi bankacılık alanıyla (Štavljanin ve Pantović, 2017; Mbama ve Ezepue, 2018; Mbama vd., 2018; Aydın ve Onaylı, 2020; Esen, 2020; Sayed ve Sayed, 2020; Shin, 2021) ilgilidir. Bankacılık sektöründeki araştırmaların bir kısmı da müşteri deneyimini ölçmek amacıyla yapılan ölçek geliştirmeye (Klaus ve Maklan, 2012; Garg vd., 2014; Kuppelwieser ve Klaus, 2021) yönelik çalışmalardır.

Bu çalışmanın amacı, bankacılık sektöründe müşteri deneyimi literatürüne bağlı olarak son 30 yıl içerisinde oluşan kelime bazlı kümeleri ve bu kümelerin alt unsurlarını belirlemektir. Bu amaçla Vosviewer programı yardımıyla 1991-2020 yıllarında arasında yapılan ve WOS veri tabanında taranan makaleler bibliyometrik analize tabi tutulmuştur. Bu çalışma bankacılık sektöründe müşteri deneyiminin gelişim yönünü ortaya koyması adına literatürdeki önemli bir boşluğu da doldurmaktadır. Çalışmada ilk olarak müşteri deneyimi kavramına ilişkin genel çerçeve sunulmuştur. Sonrasında bankacılıkta müşteri deneyimi ile ilgili çalışmalarla ve elde edilen sonuçlarla ilgili literatür değerlendirmesi yapılmıştır. Metodoloji bölümünde bibliyometrik çalışmanın araştırma süreci açıklanmış ve sonrasında gerçekleştirilen analizlerin sonuçları sunulmuştur. Sonuç bölümünde ise araştırma bulguları teorik ve pratik açıdan değerlendirilmiş ve gelecekteki araştırmalar için öneriler sunulmuştur.

\section{LITERATÜR TARAMASI}

\subsection{Müşteri Deneyimi Kavramı ve Gelişimi}

Pazarlama alanında deneyim konusu ilk olarak, müşteri davranışlarını anlamada önemli bir unsur olan Hirschman ve Holbrook'un (1982) hedonik tüketim üzerine olan çalışmasında kavramsallaştırılmıştır (Holbrook, 2000; Gentile vd., 2007; Lemon ve Verhoef, 2016; Rather, 2020). Bununla birlikte, daha önceki dönemlerde tüketim deneyimi alanına katkıları olan çalışmalar da olmuştur (Holbrook, 2000: 178-179). İlk çalışmalarda müşteri satın alma karar süreci rasyonel değerlendirmeler olarak tanımlanırken, Holbrook ve Hirschman (1982) gibi sonraki araştırmacılar tüketicilerin seçiminde duyguların rolünü araştırmış ve tüketicinin tüketim davranışında hedonik duyguların faydacı yargılara göre önemini belirtmiştir. Bu 


\section{G. Alkaç Özdemir - M. H. Altıntaş 13/2 (2021) 1856-1871}

çalışmaların devamında deneyimlerin türüne özgü çalışmalar yapılmaya (Arnould ve Price, 1993; Carù ve Cova, 2003) başlanmıştır. Oliver (1980) tarafından gerçekleştirilen müşteri memnuniyeti çalışması, Zeithaml (1988) tarafından gerçekleştirilen algılanan fiyat, algılanan kalite ve algılanan değer başlıklı çalışma, Parasuraman vd. (1988) tarafından geliştirilen SERVQUAL hizmet kalite ölçeği ve Bitner (1990) tarafından gerçekleştirilen hizmet karşılaşmalarını değerlendirmeye yönelik çalışmalar müşteri deneyimi literatürünün gelişmesine katkıda bulunmuştur. 2000'li yıllardan itibaren özellikle Verhoef vd. (2009) müşteri deneyimi sürecini ve uygulamasını perakendecilik bağlamında ele alarak müşteri temas noktalarını ve satın alma yolculuğunu vurgulayarak müşteri deneyimi literatürünün gelişimine önemli bir bakış açısı sağlamıştır. Bu dönemde Prahalad ve Ramaswamy (2004) ile Nambisan ve Baron (2009) gibi yazarlar ise müşterilerin yarattığ1 değere odaklanarak birlikte değer yaratma konusunu ele almışlar ve çalışmalarında deneyim yaratmada müşterilerin rolünün önemini ifade etmişlerdir. 2000 ile 2010 yılları arasını kapsayan bu dönem hem müşteri odaklılığını hem de müşteri odaklılı̆̆ının tüm işletmeye yerleştirilmesini amaçlayan bir dönemi içermektedir (Lemon ve Verhoef, 2016). Sonraki yıllarda ise akademik yazında çeşitli sektörlerde müşteri deneyimin ölçümüne odaklanılmıştır. Özellikle perakendecilik, turizm ve bankacılık gibi sektörlerde birçok çalışmanın yapıldığı görülmektedir.

Tüketimin deneyimsel yönleri Pine ve Gilmore'un (1998) çalışmasında incelenmiştir. Bu çalışmalarında yazarlar tüketimin deneyimsel yönleriyle ekonomilerin nasıl değiştiğini ele almışlar ve deneyimi emtia, mal ve hizmetlerden sonraki aşama olarak ifade etmişlerdir. Yine aynı çalışmada deneyimin, taklit veya ikame edilmesi zor olan ve işletmeye rekabetçi fayda yaratan bir ekonomik teklif olduğu da ifade edilmiştir. Schmitt (1999) ise Deneyimsel Pazarlama isimli çalışmasında, işletmelerin, müşterilerin markaları ve işletmeleri hissetmelerini, düşünmelerini, harekete geçmelerini ve bunlarla ilişki kurmalarını sağlayarak deneyimsel pazarlamayı nasıl oluşturabileceklerini ele almıştır (Schmitt 1999). Carbone ve Haeckel (2005) deneyimi, "insanların ürünler, hizmetler ve işletmelerle karşılaşmalarının oluşturduğu izlenim, insanların duyusal bilgiyi pekiştirdiğinde üretilen bir algı" olarak tanımlamıştır. Müşteri deneyimi, müşteri ile bir ürün, işletme veya kuruluşun herhangi bir bölümü arasındaki, müşterinin tepkilerine neden olan tüm etkileşimlerden kaynaklanmaktadır. Bu deneyim tamamen kişiseldir ve bireyin duygusal, bilişsel, fiziksel ve duyusal düzeylerde katılımını ifade etmektedir (Schmitt, 1999; Verhoef vd., 2009). Müşteri deneyimi, müşterilerin bir işletmeyle doğrudan veya dolaylı temas kurması durumunda verdikleri içsel ve öznel tepkidir. Doğrudan temasla deneyim satın alma, kullanım ve hizmet sırasında gerçekleşmekte ve genellikle müşteri tarafından başlatılmaktadır. Dolaylı temasla deneyim ise müşterilerin bir işletmenin ürünleri, hizmetleri veya temsilcileriyle ağızdan ağıza öneriler, eleştiriler, reklamlar, haberler, incelemeler şeklinde planlanmamış karşılaşmalarını içermektedir (Meyer ve Schwager, 2007: 2; Verhoef vd., 2009: 32). Deneyim, bir işletme (marka/ürün/hizmet) ile bir müşteri arasındaki, müşterinin ve ürünün, işletmenin veya markanın özellikleriyle şekillenen ve her zaman içerdiği bağlamdan/ortamdan etkilenen bir etkileşimdir (Same ve Larimo, 2012; Ferreira ve Teixeira, 2013). Lemon ve Verhoef (2016) müşteri deneyimini, müşterinin satın alma yolculuğu uyaranlarına verdiği bilişsel, duygusal, davranışsal, duyusal ve sosyal tepkilerin bütünü olarak tanımlamaktadır. Yazarlar çalışmalarında, müşterinin tüm satın alma yolculuğu boyunca temas kurduğu çoklu temas noktalarını önemini ifade etmektedirler.

Müşteri deneyimi, müşterinin geçmiş deneyimlerini, arama sürecini, bir ürünün satın alımını ve tüketimini ve ayrıca tüketicilerin birden fazla kanal üzerinden bir ürün için hizmet talep edebilecekleri satış sonrası aşamayı da kapsayan müşterinin bütünleşik deneyimini ifade etmektedir (Siqueira vd., 2020: 2). Müşterinin bu deneyimi değerlendirmesi, beklentileri ile temas anlarından ve temas noktaları etkileşiminden kaynaklanan uyaranları karşılaştırmasına bağlıdır (Gentile vd., 2007; Verhoef vd., 2009: 397). Müşteriler, bir işletmeden ürün veya hizmet satın aldıklarında her zaman iyi, kötü veya nötr bir deneyim yaşarlar. Kilit nokta, işletmenin deneyimi ne kadar etkili yönettiğidir (Berry vd., 2002).

Müşteri deneyimi, literatürde farklı boyutlarda ele alınmaktadır. Gentile vd. (2007), müşteri deneyiminin boyutlarını duyusal, duygusal, bilişsel, pragmatik, yaşam tarzı ve ilişkisel bileşenler olarak önermişlerdir. Pragmatik boyut kullanıcı deneyimi ve kullanılabilirlik kavramlarını içermektedir. Fiziksel ve duyusal yönler ise birleştirilerek duyusal boyut altında ele alınmıştır. Verhoef vd. (2009: 32) göre ise müşteri deneyimi, müşterinin bilişsel, duygusal, sosyal ve fiziksel tepkilerinden oluşan bütünsel bir kavram olduğunu belirtmektedir. Brakus vd. (2009) müşteri deneyimini bir marka ile olan deneyim olarak ele aldıkları çalışmalarında, marka deneyimini tüketicinin öznel ve içsel, markayla ilgili uyaranlar tarafından harekete 


\section{G. Alkaç Özdemir - M. H. Altıntaş 13/2 (2021) 1856-1871}

geçirilen duyusal, duygusal, bilişsel ve davranışsal tepkiler olarak ele almışlardır. Sonraki yıllarda müşteri deneyimi boyutlarının, araştırma bağlamına göre farklı sayıda ele alındığı görülmektedir. Örneğin Hsu ve Tsou (2011) çalışmasında müşteri deneyimini Schmit'in (1999) belirttiği boyutlardan oluştururken, Rose vd. (2012) müşteri deneyimini bilişsel ve duygusal olmak üzere iki boyuttan oluşturmuştur. Keiningham vd. (2020) ise çalışmalarında müşteri deneyiminin boyutları olarak; bilişsel, fiziksel, duyusal, duygusal ve sosyal boyutları önermiş ve bu boyutları kullanarak müşteri deneyimini tanımlamanın yöneticilerin onu daha iyi anlamasına yardımcı olacağını ifade etmiştir. Pekovic ve Rolland (2020) ise müşteri deneyimini, müşterinin duygusal, bilişsel, duyusal, sosyal, davranışsal ve teknolojik tepkilerini bütünleştiren çok boyutlu bir kavram olarak ele almıştır. Sindhu ve Bharti (2020) ise müşteri deneyimini, müşterinin satın alma yolculuğunun tamamı boyunca işletmenin tekliflerine bilişsel, duygusal, davranışsal, duyusal ve sosyal tepkisi olarak tanımlamıştır. Molinillo vd. (2020) ise çalışmalarında, müşteri deneyiminin ölçülmesinde sadece duyusal ve bilişsel boyutları kullanmışlardır.

İşletmeler, rekabet avantajı sağlamak için, müşteri deneyimi yönetmek ve bu konuda fark yaratmak zorundadırlar (Shaw, 2007: 4). Müşteri deneyiminin önemi arttıkça, müşteri deneyimini ölçmek için farklı modeller önerilmiştir. Brakus ve diğerlerinin (2009) marka deneyim ölçeği marka kişiliği gibi tek bir müşteri deneyimi boyutunun müşteri memnuniyeti ve sadakati üzerindeki etkisine odaklanmıştır. Klaus ve Maklan (2012) deneyim kalite ölçeği geliştirene kadar müşteri deneyimi ayrıntılı bir şekilde ölçülüp analiz edilmemiştir. Deneyim kalite ölçeğinde, müşteri deneyimi müşterinin satın alma bağlamında bir işletmeyle olan doğrudan ve dolaylı tüm karşılaşmalarının bilişsel ve duygusal değerlendirmesi olarak tanımlanmıştır. Müşteri deneyiminin önemiyle birlikte akademik yazında çeşitli bağlamlara özgü müşteri deneyim ölçekleri geliştirilmeye başlanmıştır. Ancak Palmer'ın (2010: 202) da belirttiği gibi, bağlama özgü değişkenlerin karmaşıklı̆̆ nedeniyle müşteri deneyimini ölçmeye yönelik bir ölçeğin geliştirilmesinde çeşitli zorluklar bulunmaktadır. Bir diğer ifadeyle müşteri deneyiminin uygulanabilir olarak kabul edilebilir bir ölçeğini geliştirmedeki en büyük sorun, bağlama özgü değişkenlerin farklılığı ve karmaşıklı̆̆ıdır.

Gelişen teknoloji, müşteri deneyimi üzerinde önemli etkilere sahiptir. Teknolojik gelişmeler, müşterilere ürün veya hizmetlere çok sayıda kanaldan erişme olanağı vermektedir. Müşterilerin masaüstü, dizüstü bilgisayar ve mobil cihazlar gibi farklı kanallar ve cihazlar arasında geçiş yapabilmesi müşterilere çok kanallı deneyim sunmaktadır. Özellikle, farklı kanallar ve temas noktaları, müşterilerin perakende deneyimini kolaylaştırmak için hem müşteriler hem de işletmeler tarafından sürekli, birbirinin yerine ve aynı anda kullanılabilmektedir (Verhoef vd., 2015: 176). Örneğin, çoklu kanalın bir evrimi olarak algilanan bütünleşik kanal günümüzde müşterilerin, aynı işlem sürecinde çevrimiçi, mobil cihazlar ve fiziksel mağaza arasında serbestçe hareket etmesine olanak sağlamaktadır (Piotrowicz ve Cuthbertson, 2014: 6).

Müşteri deneyimi birçok çalışmada müşteri memnuniyeti, müşteri sadakati, tekrar satın alma niyeti ve ağızdan ağıza iletişim gibi sonuçlarla ilişkilendirilmektedir. Etkin bir müşteri deneyimi sunmanın daha yüksek müşteri memnuniyeti, daha yüksek alışveriş sıklığı ve daha büyük cüzdan payı yaratma gibi farklı olumlu etkiler yaratabileceği belirtilmektedir (Pekovic ve Rolland, 2020). Örneğin Chahal vd. (2015) çalışmasında müşteri deneyiminin marka değeri, memnuniyet ve ağızdan ağıza iletişim kavramlarıyla etkileşimli olduğunu bulmuştur.

\subsection{Bankacılıkta Müşteri Deneyimi}

Günümüz tüketici ekonomisinde, müşterileri çekmek ve uzun vadede önemli ölçüde elde tutmak, her tür işletme için önemli bir zorluktur. Müşteri, tüm işletme faaliyetlerinin merkezinde yer almaktadır. Bu anlamda özellikle bankalar personelini, müşterilerin ihtiyaçlarını son derece özelleştirilmiş ve duyarlı bir şekilde karşılayacak şekilde konumlandırarak organize etmektedirler (Sharma ve Chaubey, 2014).

Bankacılık sektöründe müşteri deneyimine ilişkin yapılan akademik çalışmaların bir kısmı geleneksel bankacılık ile ilgili iken, diğer bir kısmı da dijital bankacılıkla ilgilidir. Çalışmaların bazılarında ölçek geliştirmeye odaklanılmış, bazılarında ise müşteri deneyimi ölçülmeye çalışılmıştır. Örneğin Garg vd. (2012) bankacılıkta müşteri deneyimini ölçmek için müşteri deneyimine etki eden kritik başarı faktörlerini belirlemeyi amaçladığı çalışmalarında kolaylık, çalışanlar, çevrimiçi işlevsel öğeler ve hizmet ortamı gibi faktörlerin bankalarda müşteri deneyimini ölçmede kritik değere sahip olduğunu bulmuşlardır. Bu çalışmada müşteri deneyimine etki eden en önemli unsur kolaylık faktörü olarak bulunmuştur. Benzer şekilde Garg vd. (2014: 108) bireysel bankacılık hizmetlerine ilişkin geliştirdiği ölçekte çok boyutlu bir yapı tespit etmiştir. 


\section{G. Alkaç Özdemir - M. H. Altıntaş 13/2 (2021) 1856-1871}

Kolaylık faktörünün en önemli faktör olarak çıktığı ölçekte müşteri etkileşimi, çalışanlar, hız, hizmet ortamı, temel hizmet, çevrimiçii işlevsel öğeler, diğer müşterilerin varlı̆̆ı, katma değer, hizmet süreci ve çevrimiçi estetik diğer faktörler olarak bulunmuştur. Diğer yandan müşteri deneyim kalitesi (EXQ) ölçeği geliştirmeye yönelen çalışmalar mevcuttur. Klaus ve Maklan (2012) çalışmasında müşteri deneyimini 4 boyut altında toplamıştır. Bu boyutlar; ürün deneyimi, sonuç odaklılık, gerçeklik anları ile iç rahatlığı olarak belirlenmiştir. Müşterilerin mortgage ürünlerine ilişkin deneyimleri üzerine gerçekleştirilen bu tez çalışmasında bağımlı değişkenler memnuniyet, sadakat ve ağızdan ağıza iletişim olarak belirlenmiştir. Benzer şekilde bireysel bankacılık hizmetleri üzerinde gerçekleştirdiği çalışmalarında Sharma ve Chaubey (2014), müşteri deneyimini etkileyen faktörleri 7 boyutta ele almıştır. Bu boyutlar; kolaylık, pozitif bakış açısı, cevaplanabilirlik, teknolojik destek, ambiyans, profesyonellik ve pazarlama destek hizmetleridir. Yine banka müşterileri üzerinde gerçekleştirdikleri çalışmalarında Fernandes ve Pinto (2019) bireysel bankacılık müşterilerinin ana bankalarıyla yaşadıkları deneyimlerine ilişkin çalışmalarında, ilk kademe hizmet personeli, gerçeklik anları ve ürün sunum boyutlarının müşteri deneyim kalitesini etkilediğini tespit etmiştir. Makudza (2020) ise müşteri deneyim yönetimi boyutlarını fiziksel etkileşim, sanal etkileşim ve hizmet etkileşimi şeklinde üç boyutta ele almıştır. Bireysel bankacılık sektöründe yapılan ve bankacılık hizmetleri sektörü için müşteri deneyim yönetimi (CEM) için uygun bir model geliştirmeyi amaçlayan Heshmati vd. (2019) ise çalışmalarında marka deneyimini makro ve mikro kategori olmak üzere iki boyutta ele almıştır. Makro boyutta, marka deneyimi (hizmet karşılaşmasından önce), hizmet deneyimi (hizmet karşılaşması sırasında) ve satın alma sonrası deneyim (karşılaştıktan sonra) başlıkları ile ele alınmıştır. Mikro boyutta ise alt boyutlar reklam yoluyla deneyim, marka vaatleri, sözlü öneriler, insan faktörleri, fiziksel faktörler, yapısal faktörler, destek, problem çözme, müşteri hizmetleri şeklinde ele alınmıştır.

Teknolojik gelişmelerden en çok ve öncelikli olarak etkilenen sektörlerden birisi bankacılık sektörüdür (Paçan Özcan vd., 2019). Bilgi ve iletişim teknolojilerinde yaşanan gelişmelerin etkisiyle dijital müşteri deneyimi, teknolojik gelişmelerin ve çevrimiçi ortamın öneminin artması sonucunda bankacılıkta giderek daha önemli hale gelmiştir (Aydın ve Onaylı, 2020). Dijital teknolojilerin kullanımı ile müşteri deneyiminin bankalar için önemi de artmıştır. Günümüzde üstün müşteri deneyimi yaratamayan bankalar sürdürülebilir rekabet avantajı sağlayamazlar. Dijital bankacılığın ilk aşaması internet ile gerçekleşirken, ikinci aşamayı mobil uygulamalar oluşturmuştur (Akın, 2020). Dijital bankacılık, bankacılık ürün ve hizmetlerinin dijital kanallar yoluyla sağlanması ve bankacılık faaliyetlerinin sanal platformlar üzerinden gerçekleştirilmesi olarak ifade edilebilir (Aydın ve Onaylı, 2020). Bu alana ilişkin olarak dijital bankacılık üzerinde yaptığı çalışmasında Mbama ve Ezepue (2018) müşteri deneyiminin müşteri memnuniyeti, müşteri sadakati ve finansal performansı etkilediği sonucuna ulaşmıştır. Araştırma sonucunda ayrıca algılanan değer, fonksiyonel kalite, dijital bankacılık hizmet kalitesi, çalışan müşteri etkileşimi, algılanan risk ve algılanan kullanışlılık faktörlerinin müşteri deneyimi üzerinde anlamlı etkiye sahip olduğu bulunmuştur. Shin (2021) ise çalışmasında, yararlılık, kolaylık, çalışan-müşteri katılımı ve güvenlikten oluşan dijital bankacılık deneyiminin memnuniyeti ve yeniden kullanım niyetini nasıl etkilediğini ve müşteri memnuniyetinin müşteri deneyimi ile yeniden kullanım niyeti arasındaki ilişkiye nasıl aracılık ettiğini incelemiştir. Çalışma sonucunda, müşteri deneyimi değişkeninin memnuniyet yoluyla yeniden kullanım niyetini olumlu etkilediği bulunmuştur.

Yukarıda ele alınan literatür incelemesinde de görüldüğü gibi müşteri deneyiminin çok farklı sektörlerde ve çok farklı bağlamlarda ele alındığı görülmektedir. İşletmelerin başarılı olmasında hem pratikteki yayınlar hem de akademik yayınlar aynı yönde düşünmektedir. Hizmet sektöründe önemi daha fazla olan müşteri deneyiminin en çok önemsendiği sektörlerden birisi de bankacılık sektörüdür. Emek yoğun olan bu sektörde hizmet karşılaşmalarına ilişkin belirli temas noktalarının olması ve bu temas noktalarının da müşteri deneyimi üzerindeki etkileri olağandır. Bankacılık sektöründe müşteri deneyimi ile ilgili literatürün genişlemesi de konunun pratik hayat açısından olduğu kadar akademik açıdan da önemli olduğunu göstermektedir.

Müşteri deneyimine ve müşteri deneyimi kavramının bankacılık alanındaki yansımalarına ilişkin teorik çerçeve sonrasında, bankacılıkta müşteri deneyimine ilişkin bibliyometrik analize ait araştırma aşaması aşağıda ele alınmış ve elde edilen bulgular sunulmuştur. 


\section{METODOLOJi}

\subsection{Amaç}

Çalışmanın amacı, bankacılıkta müşteri deneyimi kavramının araştırmacılar tarafından literatürde hangi yönde kullanıldığının ve zaman içerisinde olgunlaşan ana kümelerin alt unsurlarının belirlenmesidir. Bu bağlamda bankacılıkta müşteri deneyimi alanında yazılmış olan makalelerinin kelime bazlı yansımaları ve genel profili çıkarılmıştır. Çalışma, bibliyometrik analiz yönteminin gereği ve içeriği olarak zamansal yansımaları göstermektedir. Bu kapsamda çalışmanın araştırma soruları şunlardır:

- Bankacılıkta müşteri deneyimi kavramının zaman içerisinde olgunlaşan ana kümeleri nelerdir?

- Bu ana kümelerin bağlantılı olduğu alt-kümeler nelerdir?

- Alana ilişkin yıllar içerisindeki makale sayıları ne kadardır?

- Alana ilişkin dergilerin ağırlıkları nedir?

- Alana ilişkin yazarların ağırlıkları nedir?

\subsection{Yöntem}

Bibliyometrik çalışmalar belirli bir alanın gelişimine odaklanan yöntem olarak, bir alanda ön planda olan dergilerin incelenmesi (Donthu vd., 2020) şeklinde olduğu gibi ilgili disiplinin içeriğine yönelik de (Kraus vd., 2020) gerçekleştirilebilir. Böylece kavramın genel yapısının dönüşümü belirlenebilmektedir (Taqi vd., 2019). Diğer yandan gelişen, değişen olguların tespiti için de bibliyometrik analiz sonuçları önemlidir (Nicolas vd., 2020). Eş-oluşum (co-occurrence) yöntemi de anahtar kelimeler bazında kelimelerin eşleştirilmesi temelinde bir haritalandırmaya atıf yapmaktadır (Sedighi, 2016). Bu bağlamda VOS tekniğinin çok boyutlu ölçeklemeye göre eş-oluşum yöntemiyle daha tatminkar sonuçlar verdiği görülmektedir (Van Eck vd., 2010: 2414). Sistem, matris sistemine dayanarak (Liu ve Mei, 2016) ağ veya kümelerin oluşmasına odaklanmaktadır (Qiu vd., 2014; Cheng vd., 2018). Bu bağlamda bu çalışmanın araştırma ve analiz aşamasında, bankacılıkta müşteri deneyimi anahtar kelimesine yönelik bibliyometrik analiz eş-oluşum yöntemiyle gerçekleştirilmiştir. Müşteri deneyimi konusuna ilişkin literatürde belirli sayıda çalışmanın yapıldığı görülmektedir. Bu çalışmalar, daha çok zaman periyodu olarak kavramsal dönüşüm (Ferreira ve Teixeira, 2013; Sindhu ve Bharti, 2020) ile atıf ve eş-atıf üzerinde yapılan bibliyometrik çalışmalar kapsamında gerçekleştirilmiştir (Silva vd., 2020). Bankacılık alanında gerçekleştirilen bibliyometrik çalışmalar incelendiğinde, eş-kelime analiziyle sürdürülebilir bankacılık (Aracil vd., 2020), anahtar kelimeye dayalı ă analizi açısından bankalarda yolsuzluk (Bahoo, 2020), eş-kelime temelli İslami Bankacılık (Biancone vd., 2020), eş-oluşumlu olarak tüketici kredi davranışı (Carlsson vd., 2017) ve banka hizmetlerine sadakat (Dubina vd., 2020), mobil bankacillk (Gupta vd., 2017; Preciado-Ortiz vd., 2018) ve yeşil bankacılık (Sarma ve Roy, 2019) konularında çalışmaların olduğu görülmektedir.

\section{BULGULAR}

\subsection{Veriler}

Bibliyometik analizi için gerekli olan veri seti Web of Science (WOS) veri tabanından elde edilmiştir. WOS Institute for Scientific Information (ISI) tarafından geliştirilen dünyanın en büyük yayıncıdan bağımsız bilimsel bir atıf indeksleme veri tabanıdır. Veriler, WOS veri tabanından 29-30 Mart 2021 tarihinde girilen anahtar kelimeye göre elde edilmiştir. Anahtar kelime "customer experience - banking" olarak belirlenmiştir. Tarama konu olarak gerçekleştirilmiştir. Veri seti, İşletme ve Yönetim (Business and Management) alanında İngilizce olarak yazılan ve 1991-2020 yıllarında yayınlanan makalelerden oluşmaktadır. WOS veri tabanından verilerin alındığı 29-30 Mart 2021 tarihinde toplam 293 makale tespit edilmiştir. Tek bir dönemin ele alınmasının nedeni ilgili kavramın genel alan yazının görünümünü belirlemektir. Analiz VOSviewer programıyla gerçekleştirilmiştir. Veriler değerlendirilirken benzer kelimeler hem benzerlik hem de anlam olarak birlikte değerlendirilmiş ve programda sözlük olarak derlenmiştir. Ayrıca verilerden ülkeler ve ülkelerle ilgili bilgiler analiz dışı tutulmuştur. Toplam 876 kelime, 40 alt unsurlu 8 küme saptanmıştır. Şekiller kümelerin ve üyelerinin toplam link ağırlı̆̆ olarak verilmiştir. Ayrıca customer experience kavramının üyesi olduğu kümenin içeriği de incelenmiştir. 


\subsection{Alana İlişkin Genel Bulgular}

Anahtar kelimeye göre veri setinden ağ analizine geçilmeden önce verilere yönelik ilgili anahtar kelime bağlamında alana ilişkin yansıtıcı bilgiler sunulmuştur. Aşağıdaki Şekil 1'de yer alan 1991-2020 yılı arasında yayınlanan makale sayıları incelendiğinde, 2016 yılı ve sonrasında makale sayısının oldukça arttığı görülmektedir. Makale sayısına göre analiz yapıldığında bankacılıkta müşteri deneyimi kavramının yazındaki ilk döneminin 1991-2007, gelişme döneminin 2008-2015, büyüme ve yoğunlaşma döneminin ise 2016 yılı ve sonrası olduğu değerlendirilebilir.

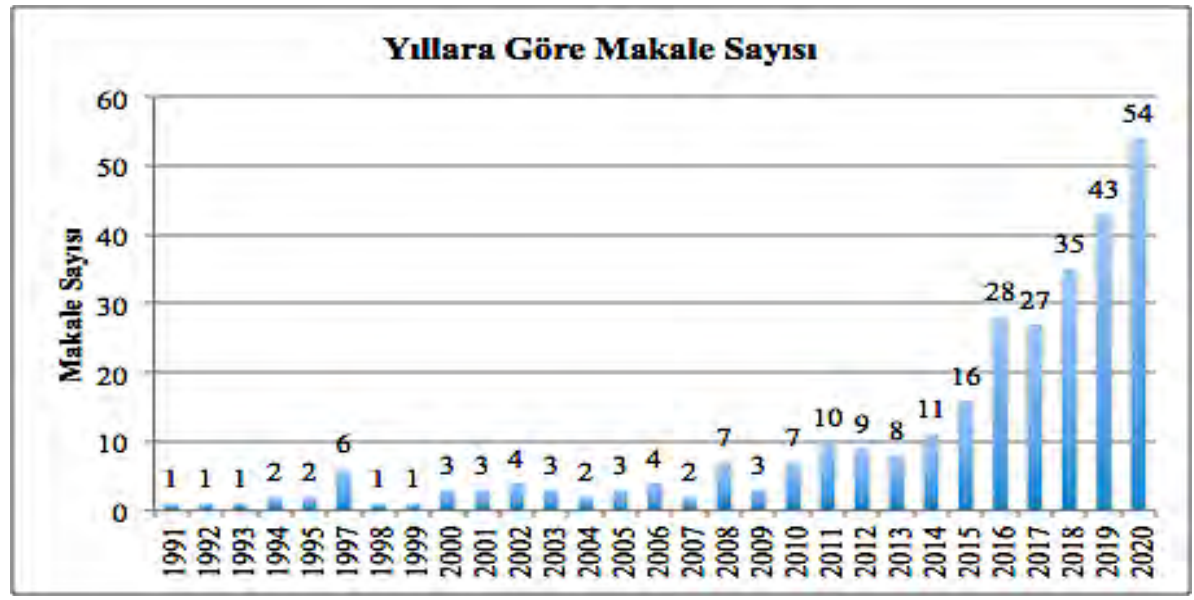

Şekil 1. Yıllara Göre Makale Sayısı

İlgili yazının hangi araştırma alanlarında yapıldığı aşağıdaki Şekil 2’ de görülmektedir. Şekil 2 incelendiğinde yayınların doğal olarak işletme ve ekonomi alanında yoğunlaştığı, ancak diğer yandan bilgisayar bilimi, mühendislik alanı ve bilgi biliminde yayınlanan makale sayısının da dikkate değer bir sayıda olması bankacıllğın son dönemlerde dijitale yönelmesinin bir yansıması olarak değerlendirilebilir. Diğer yandan ilgili kavramın değişik araştırma alanlarının da kendine yer bulduğu görülmektedir.

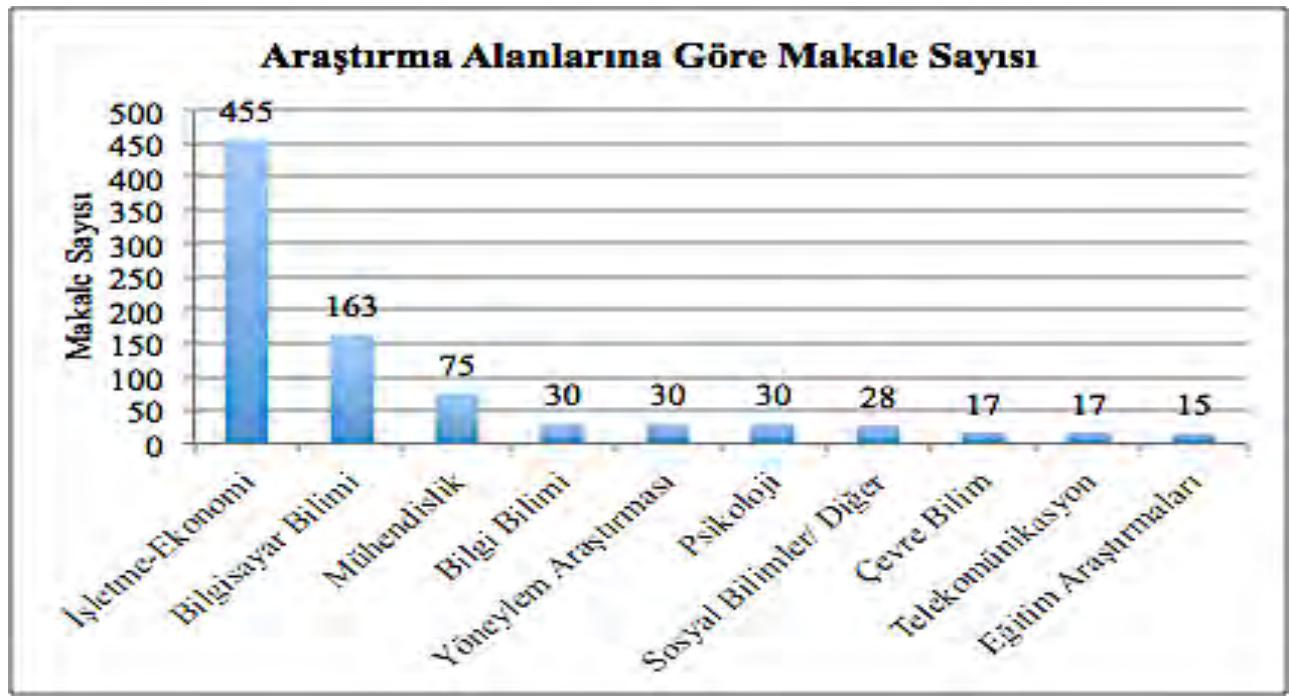

Şekil 2. Araştırma Alanlarına Göre Makale Sayısı

Belirli bir alanın gelişmesi ve farkındalığının artması o alanda yayınlanan dergiler ile yakından ilgilidir. Aşağıdaki Şekil 3'de görüldüğü üzere makalelerin toplamı üzerinden değerlendirme yapıldığında, ilgili alandaki yayınların yaklaşık \%15'inin International Journal of Bank Marketing (Uluslararası Banka Pazarlama Dergisi) dergisinde olduğu görülmektedir. Bu sonuç, ilgili derginin doğrudan alana ilişkin bir dergi olmasından kaynaklandığı şeklinde ifade edilebilir. Diğer dergiler hizmet sektörüyle ilişkili dergilerdir. Aşağıdaki Şekil 3’de ilk 10 dergi ve bu dergilerde yayınlanan makale sayıları verilmiştir. 


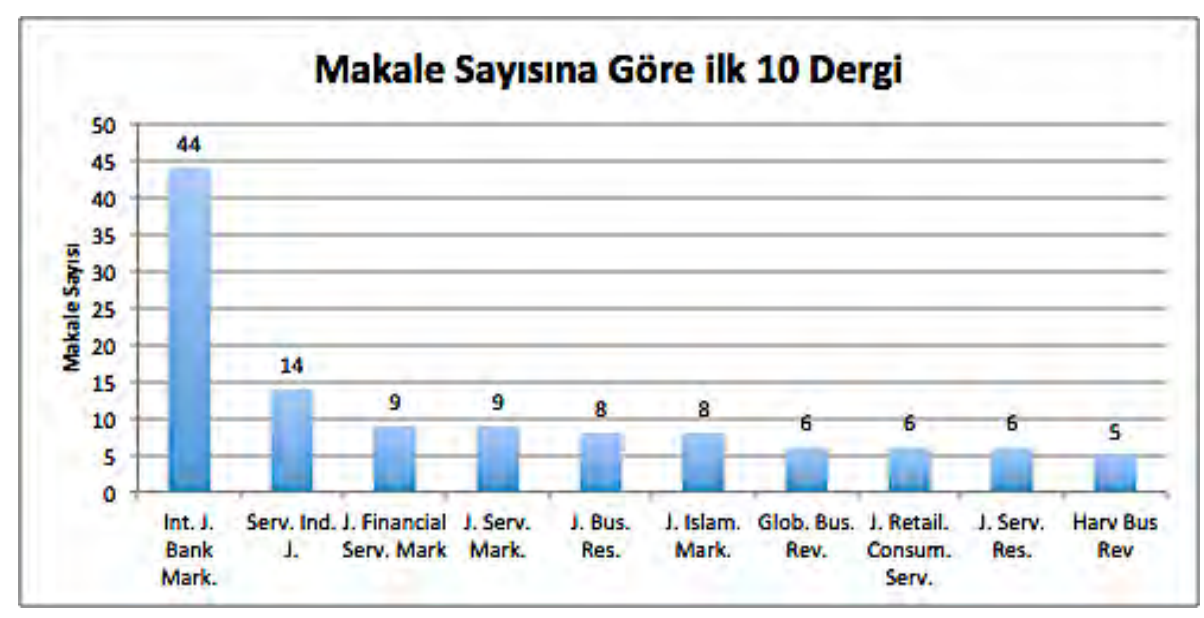

Şekil 3. Makale Sayısına Göre İlk 10 Dergi

Bir alanın önemli ve sürükleyici aktörlerinden bir diğeri de o alanda eser yayınlayan yazarlardır. Bu kapsamda atıf sayısı en yüksek ilk 10 yazar aşağıdaki Şekil 4'de gösterilmiştir. Yazarlar arasında Schneider, B.; Paul, M.C. ve White, S.S. ilk üç yazarı oluşturmaktadır.

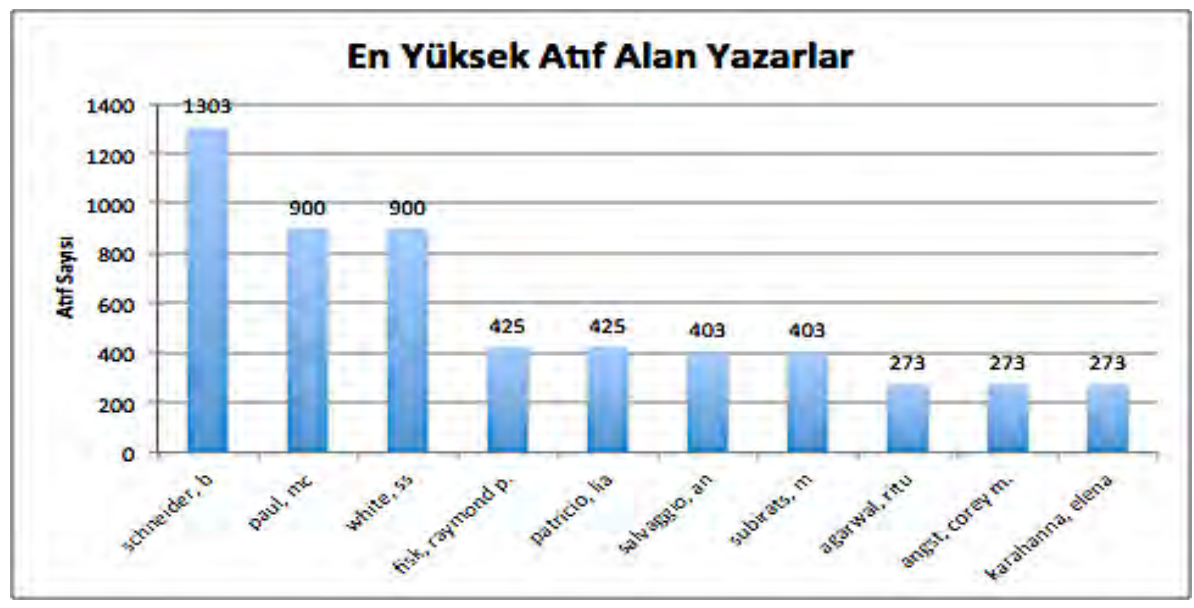

Şekil 4. Atıf Sayısına Göre İlk 10 Yazar

Şekil 4 incelendiğinde ilk üç yazarın atıf sayılarının diğer yazarlara göre oldukça yüksek olduğu görülmektedir.

\subsection{Bibliyometrik Analiz Sonucu Bulunan Kümeler ve Ăg İlişkileri}

Bibliyometrik analiz ile bankacılıkta müşteri deneyimine ilişkin kümeler ve ağlar belirlenmiştir. Gerçekleştirilen analiz sonucunda müşteri deneyiminin müşterinin bankacılık hizmetleri ve uygulamalarıyla kurduğu etkileşimin bir karşılığı olarak sekiz kümede incelenmesinin olası olduğu bulunmuştur. Birinci küme daha çok çevrimiçi hizmetler de dahil olmak üzere müşterilere sunulan hizmetin adilane dağıtılmasını ifade etmektedir. Hizmet sektöründe üretim ve tüketim eş anlı gerçekleştiği için adilane davranma sistematiğinin, hizmet dışı alanlara yönelik tüketim algoritmasında dikkate alınan etkileşim adaleti bağlamında önemli olduğu ifade edilebilir (Aurier ve Siadou-Martin, 2007). Çünkü müşteri deneyimi bir etkileşim modellemesi bağlamında kavramsallaştırılmakta, ortama yönelik motivasyon alanında etkileşimin alt unsurlarının önemli olduğu belirtilmektedir (Von Saucken vd., 2012).

İkinci küme, ağırlıklı olarak teknoloji kabul davranışı ile ilgilidir. Teknoloji kabul modeli (TAM modeli) özellikle elektronik ortamlara yönelik hem cinsiyet hem de diğer olgular açısından dikkate alınan yapılardır. Cinsiyetin teknolojiye uyumu konusunda sistemle bütünleşebilme ve sistemi algilayarak kullanabilme konusunda aracı bir etkiye sahip olup olmadığı incelenmektedir (Pandey ve Chawla, 2018). Özellikle ebankacılıkta müşterilerin bireysel özellikleri ile sistemin alt yapısı ve tasarımını kabul modeli üzerinde etkili unsurlar olarak modelleyen çalışmalar mevcuttur (Medyawati vd., 2011). 


\section{G. Alkaç Özdemir - M. H. Altıntaş 13/2 (2021) 1856-1871}

Üçüncü küme incelendiğinde, değer odaklı hizmet kalitesi ve tavsiyenin önemli olduğu görülmektedir. Müşteri deneyiminin olumlu olması insanların çevrelerine ilgili hizmeti tavsiye etme eğilimini arttırmaktadır (Klaus ve Maklan, 2013; Cetin ve Dincer, 2014). Dolayısıyla bibliyometrik çalışmadan elde edilen bu sonuç, teorik olarak müşteri deneyimi ve ardılları arasındaki ilişkiyi göstermektedir.

Dördüncü küme elemanlarının ise daha çok deneyimi hissetme ve yaygınlaştırma odaklı olduğu görülmektedir. Özellikle bütünleşik kanal bağlamında deneyimin çoklu kanallara aktarılması güçlü bir araç olarak kullanılabilir. Literatürde bütünleşik kanalların yapısı gereği süreci hızlandırması, ihtiyacın daha bütüncül giderilmesi (Cook, 2014) ile özellikle bankacılık hizmetlerinde mevcut ve gelecek deneyim algılarını olumlu ve olumsuz etkileyen nitelikler olarak belirtilmektedir (Komulainen ve Makkonen, 2018).

Beşinci küme ise daha çok genel hatlı olmakla birlikte hizmeti algılamaya yönelik alt unsurlardan oluşmaktadır. Hizmetin sektöründe sunulan pazarlama faaliyetleri ile müşterinin memnuniyet hissi yaşaması bunu destekleyen bir olgudur. Müşteri deneyimini pazarlama mantığı çerçevesinde inceleyen Homburg vd. (2017) kavramın çerçevesinin müşteri temas noktaları etrafında olgunlaştırılarak kültürel, stratejik ve işletme temelli yapılara göre analizini önermektedir.

Altıncı küme marka odaklılığı ifade etmektedir. Müşteri deneyiminin önemli ardıllarından marka deneyimi kavramsallaştırma açısından etkili bir bulgudur. Müşteri deneyiminin markanın oluşturmaya çalıştığı marka konumu ve kimliği üzerinde etkili bir araç olarak modellendiği görülmektedir (Wallace vd., 2013).

Müşteri ile çalışan etkileşimi veya hizmet ikliminin kavramın iç dinamiklerinden biri olduğu yedinci kümede görülmektedir. Hizmet çalışanlarının yapısı ve özelliklerinin, müşteri açısından sosyal bir ortam olarak algıladığı etkileşimin müşteri deneyimini belirleyen bir unsur olmasında (Srivastava ve Kaul, 2014) karşılıklı etkileşimin önemi ortaya çıkmaktadır.

Son küme ise daha çok müşteri yapısına atıf yapmaktadır. Marka değerinin sunulması ve deneyimin bir bölümlendirme aracı olarak kullanılması teorik yapıyı desteklemektedir. Müşteri deneyimi kullanıcı deneyiminin marka sermayesi üzerindeki etkisinde aracı bir role sahiptir. Bu durum, müşteri deneyiminin sistemi düzenleyen bir unsur olarak ele alındığını göstermektedir (Lee vd., 2018). Diğer yandan doğrudan etkilemesinin bir sonucu olarak müşteri deneyiminin bağımsız bir kavram niteliğinde olduğu da ifade edilmektedir (Biedenbach ve Marell, 2010).

Tablo 1. A ̆g Kümelerini Oluşturan Kavramlar

\begin{tabular}{|c|c|c|c|}
\hline $\begin{array}{l}\text { Küme 1: MÜŞTERİ } \\
\text { ADALETİ VE } \\
\text { KORUMA } \\
\text {-Bankacılık Sektörü } \\
\text {-Müşteri Sayısını } \\
\text { Koruma } \\
\text {-Çevrimiçi Bankacılık } \\
\text {-Algılanan Adalet } \\
\text {-Performans } \\
\text {-İlişkisel Kalite } \\
\text {-Hizmet Telafisi }\end{array}$ & $\begin{array}{l}\text { Küme 2: TEKNOLOJI } \\
\text { ADAPTASYON } \\
\text { - Tüketici Davranışı } \\
\text {-E-Ticaret } \\
\text {-E-Hizmet Kalitesi } \\
\text {-Cinsiyet } \\
\text { - Teknoloji Kabulü }\end{array}$ & $\begin{array}{l}\text { Küme 3: DEĞER } \\
\text { ODAKLI BAĞLILIK } \\
\text { - Müşteri Sadakati } \\
\text { - Finansal Hizmetler } \\
\text { - Algılanan Değer } \\
\text { - Bireysel Bankacılık } \\
\text { - Hizmet Kalitesi } \\
\text { - Ağızdan Ağıza } \\
\quad \text { İletişim }\end{array}$ & $\begin{array}{l}\text { Küme 4: DENEYİMİ } \\
\text { HİSSETME } \\
\text {-Kritik Olay Tekniği } \\
\text { - Müşteri Deneyimi } \\
\text { - Müşteri Değeri } \\
\text { - Bütünleşik Kanal } \\
\text { - Algilanan Risk } \\
\text {-Hizmet Dağıtımı }\end{array}$ \\
\hline $\begin{array}{l}\text { Küme 5: HİZMETI } \\
\text { ALGILAMA } \\
\text {-Müşteri Memnuniyeti } \\
\text {-Müşteri Hizmeti } \\
\text {-Pazarlama } \\
\text {-Hizmet Sektörleri } \\
\text {-Hizmetler }\end{array}$ & $\begin{array}{l}\text { Küme 6: MARKA } \\
\text { ODAKLILIK } \\
\text { - Marka Angajmanı } \\
\text { - Marka Deneyimi } \\
\text { - Marka Sadakati } \\
\text { - Sosyal Medya }\end{array}$ & $\begin{array}{l}\text { Küme 7: HİZMET } \\
\text { İKLİMI } \\
\text { - Müşteri Yönelimi } \\
\text { - Müşteri İlişkileri } \\
\text { - İlk Aşama Çalışanlar } \\
\text { - Hizmet İklimi }\end{array}$ & $\begin{array}{l}\text { Küme 8: MÜŞTERİ } \\
\text { YAPISI } \\
\text {-Marka Değeri } \\
\text {-Duygular } \\
\text { - Bölümlendirme }\end{array}$ \\
\hline
\end{tabular}

Vosviewer programı sayesinde oluşturulan ve ağ haritası olarak şekillendirilen kavramlar arası ilişkiler aşağıdaki Şekilde 5’de görülmektedir. A $\breve{g}$ haritasında birbirlerine yakın duran kelimelerin makalelerde daha 


\section{G. Alkaç Özdemir - M. H. Altıntaş 13/2 (2021) 1856-1871}

yüksek eş-oluşum değerine sahip olduğu veya tam tersi uzak olanların eş-oluşum değerinin düşük olduğu görülmektedir. Ăg haritasında dairenin büyüklüğü kavramın daha önemli ve anlamlı olduğunu ifade etmektedir (Shah vd., 2020: 90). İlgili kelimelerin ilişkiler ağı aşağıdaki Şekil 5'de görülmektedir.

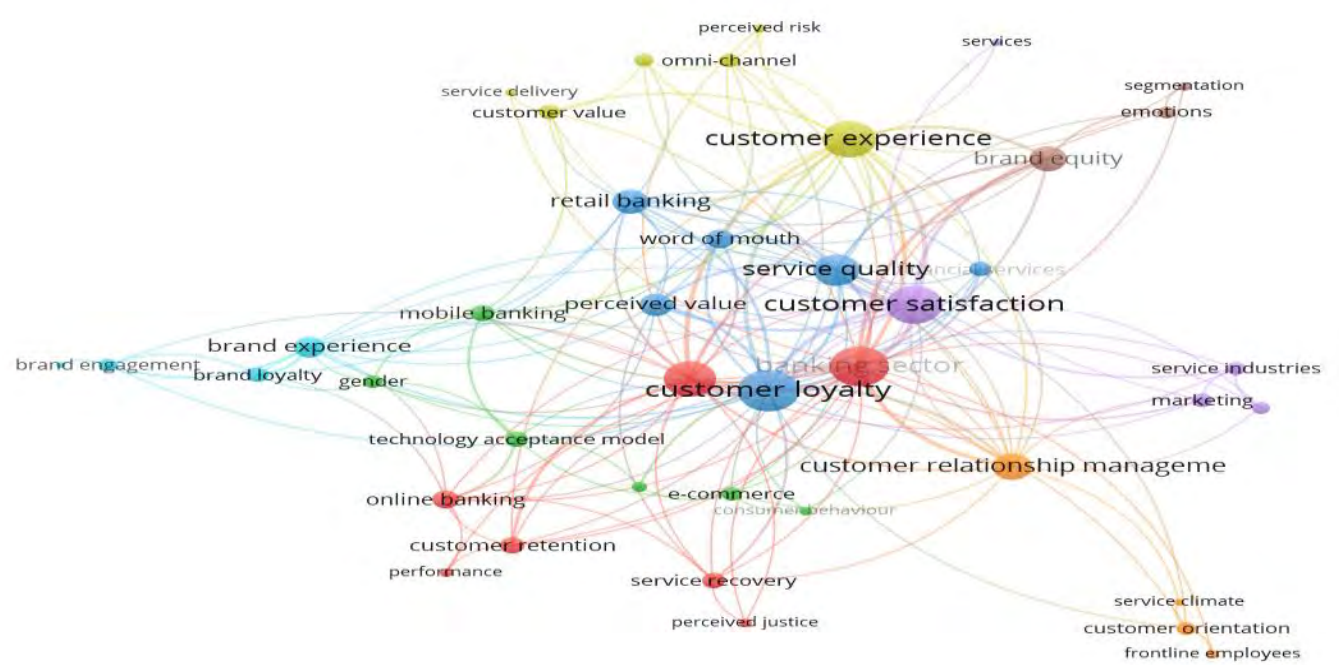

Şekil 5. Ağ Analizi: Toplam Bağıntı Gücüne Göre Temalar Arasındaki İlişkiler (Vosviewer)

Şekil 5 incelendiğinde, müşteri deneyimi kavramının ağırlıklı olarak bankacılık sektörü, müşteri sadakati, müşteri memnuniyeti, hizmet kalitesi, ağızdan ağıza iletişim, bireysel bankacılık, mobil bankacılık, marka denkliği, algılanan değer, müşteri ilişkileri yönetimi gibi konularla ilişkilendirildiği görülmektedir. A $\breve{g}$ haritasında öne çıkan bu kelimeler, müşteri deneyiminin bankacılık sektöründe özellikle bireysel ve mobil bankacılıkta ele alındığını ve müşteri deneyiminin ardılları olarak ifade edilen müşteri memnuniyeti, sadakati, ağızdan ağıza iletişim ve marka denkliği ile büyük oranda çalışıldığını göstermektedir.

Odak noktası olarak müşteri deneyimi olgusu özelinde ağ ilişkileri incelendiğinde, aşağıdaki Şekil 6’da da görüleceği üzere müşteri deneyimi alt konularının ağırlıklı olarak bankacılık sektörü, müşteri sayısını koruma, müşteri memnuniyeti, ilişki kalitesi, hizmet kalitesi, müşteri değeri, ağızdan ağıza iletişim gibi konular ile ilintilidir. Ayrıca ana hatlar olarak marka sermayesi, bölümlendirme, bankacılık sektörü, finansal hizmetler, müşteri ilişkileri yönetimine yönelik kavramların da ağ içerisinde olduğu görülmektedir.

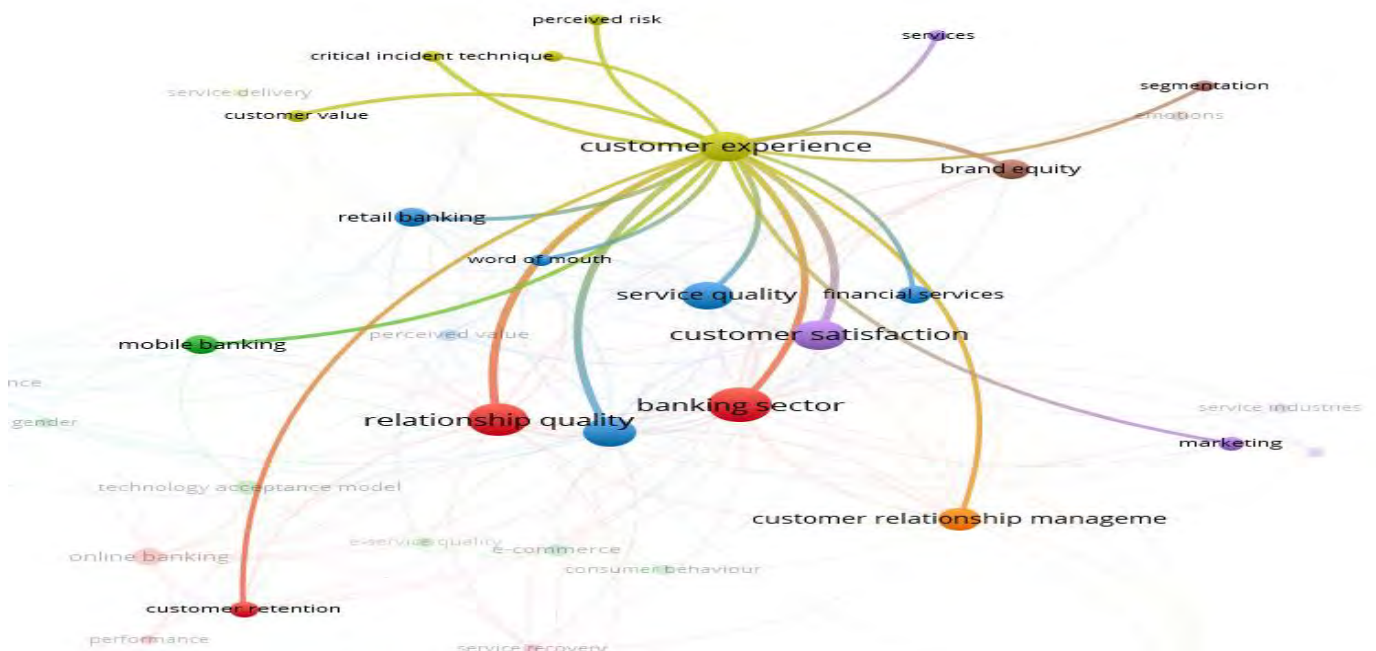

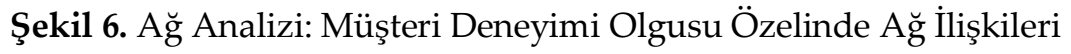




\section{SONUÇ}

Bu çalışmada bankacılıkta müşteri deneyiminin gelişim yönü ve ağırlığını ortaya koymak için ilişki ağlarının yanı sıra araştırma alanıyla ilgili öne çıkan yazarlar, dergiler ve makale sayıları değerlendirilmiştir. Çalışma müşteri deneyiminin bankacılık alanındaki temalar kapsamında yansımalarını tespit etmeye yönelik gerçekleştirilmiştir. Bibliyometrik analiz yöntemiyle ilgili kavramın tek bir zaman periyodu çerçevesinde incelenmesi (1991-2020) genel yapıyı belirleme yönünde önemli bir araştırma zemini oluşturmaktadır. Gerçekleştirilen analiz sonucunda, bankacılıkta müşteri deneyimiyle ilgili makale sayısının 2016 yılı ve sonrasında belirgin derecede arttığı, araştırma alanının doğal olarak önemli ölçüde işletme ve ekonomi alanında yoğunlaştığı, konuyla ilgili dergiler arasından özellikle International Journal of Bank Marketing dergisinin araştırmacılar tarafından daha fazla tercih edildiği görülmektedir.

Müşteri deneyimi birden çok aşamayı kapsayan bütünsel bir kavramdır. Bununla birlikte, müşteri deneyimi çok yönlü olduğu için, müşteri deneyimi parçalara ayrılmakta ve çok boyutlu bir yapı olarak (Verhoef vd., 2009) kavramsallaştırılmaktadır. Schmitt (1999) müşteri deneyimini duyusal, duygusal, bilişsel, fiziksel, sosyal deneyimler şeklinde çok boyutlu olarak tanımlamaktadır. Ana kavramların ve kümelerde yer alan altkavramların aralarındaki ilişkiler ağı bu perspektifi desteklemektedir. Her olgu gibi müşteri deneyimi de kendi iç dinamiği olduğu kadar diğer olgularla da doğrudan veya dolaylı ilişkilere sahiptir.

Çalışmanın en dikkat çekici bulgusu toplam ilişki gücü bağlamında sekiz ana kümenin saptanmasıdır. Müşteri deneyimi özelinde tekli bir ilişki ağı incelendiğinde ise müşteri yönetimi şeklinde bir çizginin belirginleştiği görülmektedir. Müş̧eri yönetimi bu anlamda müşteri deneyimi sağlanarak bölümlendirme, müşteri sayısını koruma, hizmet kalitesi, mobil bankacılık, müşteri değeri yaratma gibi eylem ve tutumların oluşumunu içermektedir. Pratik açıdan bu çalışmanın sonuçları bankaların müşterileri için müşteri deneyimi oluşturmaya ve deneyimi iyileştirmeye yönelik çabaların müşterileri elde tutma, müşteri memnuniyeti, ilişki kalitesi, müşteri değeri ve ağızdan ağıza iletişim konularında önemli çıktılarının olacağını göstermektedir. Çok boyutluluk veya çalışmanın ilgi odağı olarak düşünüldüğünde ilişki ağı, Klaus ve diğerlerinin (2013) deneyim kalitesi bağlamlı (EXQ) marka deneyimi, hizmet deneyimi ve satın alma sonrası deneyim boyutlarıyla da örtüşmektedir. Bu açıdan memnuniyet, sadakat ve WOM boyutları da müşteri deneyimi kavramıyla ilişkili bulunmuştur. Araştırmada bulunan müşteri deneyimi üzerinden müşteri yönetimi vurgusu Chahal ve Dutta'nın (2015) bankacılık sektöründe gerçekleştirdiği araştırmada, müşteri deneyiminin duygusal, duyusal, davranışsal, bilişsel ve ilişkisel boyutlardan oluşan kavramsallaştırmasıyla da örtüşmektedir.

Bibliyometrik analiz sonucunda, müşteri deneyimi konusunun önemli bir alan olarak geliştiği ifade edilebilir. Son dönemde yayınlanan makale sayısı, işletme alanındaki özellikle hizmet sektörüne yönelik dergilerin hem bankacılık hem de yan alan olarak gelişmesi, belirli yazarların bu konuya odaklanması söz konusu gelişimin göstergelerindendir. Bir alanın kendi iç kavramlarıyla olduğu kadar diğer yan kavramlar hatta farklı bilim dallarıyla etkileşime geçmesi de bu alanın kurumsallaşma sürecine girdiğini ifade etmektedir. Bankacılıkta müşteri deneyiminin mühendislik ve bilgisayar bilimi ile neredeyse eşgüdümsel gitmesi bir projeksiyon olarak dijitalleşmenin bir alan olarak bu konuda geliştiğini göstermektedir. Dolayısıyla teknolojik imkânlardan yararlanarak bankacılık sektöründe müşterilerin bütünleşik kanal deneyimini etkileyen faktörlerin belirlenmesi ve elde edilen sonuçlara göre müşteri deneyimlerini iyileştirerek müşteri memnuniyeti ve sadakatinin arttırılması sağlanmalıdır (Marangoz ve Erboy, 2020).

Bankacılık sektörü, teknoloji ve artan rekabet nedeniyle köklü değişiklikler geçirmektedir. Teknolojinin etkilerinin çokça hissedildiği ve teknolojik uygulamaların oldukça fazla kullanıldığı bankaların üst yönetimleri, teknolojinin yanı sıra müşterilerinin istek ve ihtiyaçlarının, yenilikleri kabulünün ve satın alma davranışlarının da farkında olmalıdırlar (Özdemir, 2016: 344). Bu noktada farklılaştırıcı bir araç olarak bankacılıkta müşteri deneyiminin kritik başarı faktörlerinin belirlenmesi gereklidir (Chandok ve Gupta, 2013). Buradan yola çıarak gelecekte bankacılıkta daha etkin müşteri deneyiminin, müşteri sadakati ve karlılıkta etkili olması için basit ve etkili süreçler tasarlanmalıdır. Benzersiz müşteri deneyimleri yaratmak bankaların öncelikle üzerinde durması gereken bir fırsat olarak görülmelidir. Bankalar, rekabetçiliğini sürdürmek için müşterilerin "temas noktaları" üzerinde titizlikle çalışmalıdırlar. Bu "temas noktaları" ise, müşteri ile banka arasında herhangi bir etkileşim türü gerçekleştiğinde ortaya çıkan müşteri deneyimleridir (Komulainen ve Makkonen, 2018). Bankalar, finansal teknoloji hizmeti veren diğer kurumlarla rekabette, müşteri deneyimini yönetmeyi verimliliği artırmak ve rekabetçi üstünlük sağlamak için önemli bir unsur olarak görmelidirler. 


\section{G. Alkaç Özdemir - M. H. Altıntaş 13/2 (2021) 1856-1871}

$\mathrm{Bu}$ çalışmanın sonuçları gelecekte bankacılıkta müşteri deneyimine ilişkin hangi bağlantılı konuların çalışılacağını da göstermesi açısından değerlidir. Bu konular için konuyla ilgili bulunan ağ kümelerine ilişkin sonuçlardan yararlanılabilir. Ayrıca bankacılıkta müşteri deneyimi ile ilgili yayınlar için potansiyel dergiler de ortaya konmuştur. Bu doğrultuda bu çalışmanın sonuçları gelecekteki araştırmacılara yön gösterici niteliktedir. Sonuç olarak gelecekteki araştırmacılara diğer yan alanlara ilişkin seçilecek anahtar kelimeler ile bibliyometrik analizlerin veya literatür taramasının yönünün değiştirilmesi ve genişliğinin arttırılması önerilebilir. Diğer yandan sadece WOS verileri değil, diğer indeksler kullanılarak yapılacak daha geniş ölçekli veri seti ile elde edilecek sonuçların karşılaştırmalı olarak incelenmesi de öneri olarak sunulabilir.

\section{KAYNAKLAR}

Akın, F. (2020). Dijital dönüşümün bankacılık sektörü üzerindeki etkileri. Balkan ve Yakın Doğu Sosyal Bilimler Dergisi, 6(2), 15-27.

Aracil, E., Nájera-Sánchez, J. J., ve Forcadell, F. J. (2021). Sustainable banking: A literature review and integrative framework. Finance Research Letters, (Article in Press), https://doi.org/10.1016/j.frl.2021. 101932.

Arnould, E. J., ve Price, L. L. (1993). River magic: Extraordinary experience and the extended service encounter. Journal of Consumer Research, 20(1), 24-45.

Ater, I., ve Landsman, V. (2013). Do Customers learn from experience? Evidence from retail banking. Management Science, 59(9), 2019-2035.

Aurier, P., ve Siadou-Martin, B. (2007). Perceived justice and consumption experience evaluations: A qualitative and experimental investigation. International Journal of Service Industry Management, 18(5), 450-471.

Aydın, S., ve Onaylı, E. (2020). Bankacılıkta dijital dönüşümle değişen müşteri deneyimi: Müşteri sadakati, memnuniyeti ve tavsiye eğilimine yansımaları. Yönetim Ve Ekonomi, 27(3), 645-663.

Bahoo, S. (2020). Corruption in banks: A bibliometric review and agenda. Finance Research Letters, 35, 1-13.

Berry, L. L., Carbone, L. P., ve Haeckel, S. H. (2002). Managing the total customer experience. MIT Sloan Management Review, 43(3), 85-89.

Biancone, P. P., Saiti, B., Petricean, D., ve Chmet, F. (2020). The bibliometric analysis of Islamic banking and finance. Journal of Islamic Accounting and Business Research, 11(10), 2069-2086.

Biedenbach, G., ve Marell, A. (2010). The impact of customer experience on brand equity in a business - to business services setting. Journal of Brand Management, 17(6), 446-458.

Bitner, M. J. (1990). Evaluating service encounters: The effects of physical surroundings and employee responses. Journal of Marketing, 54(2), 69-82.

Brakus, J. J., Schmitt, B. H., ve Zarantonello, L. (2009). Brand experience: What is it? How is it measured? Does it affect loyalty?. Journal of Marketing, 73(3), 52-68.

Carbone, L. P., ve Haeckel, S. H. (2005). Engineering customer experiences. IBM Executive Business Institute, https://www.researchgate.net/profile/Lewis-Carbone/publication/265031917_Engineering_Customer_ Experiences/links/55929abd08ae1e9cb42963df/Engineering-Customer-Experiences.pdf, 1-9, (Erişim tarihi: 9 Mart 2021).

Carlsson, H., Larsson, S., Svensson, L., ve Åström, F. (2017). Consumer credit behavior in the digital context: A bibliometric analysis and literature review. Journal of Financial Counseling and Planning, 28(1), 76-94.

Carù, A., ve Cova, B. (2003). Revisiting consumption experience: A more humble but complete view of the concept. Marketing Theory, 3(2), 267-286.

Cetin, G., ve Dincer, F. I. (2014). Influence of customer experience on loyalty and word-of-mouth in hospitality operations. Anatolia, 25(2), 181-194. 


\section{G. Alkaç Özdemir - M. H. Altıntaş 13/2 (2021) 1856-1871}

Chahal, H., Kaur, G., ve Rani, A. (2015). Exploring the dimensions of customer experience and its impact on word-of-mouth: A study of credit cards. Journal of Services Research, 15(2), 7-33.

Chahal, H., ve Dutta, K. (2015). Measurement and impact of customer experience in banking sector. Decision, $42(1), 57-70$.

Chandok, M., ve Gupta, N. L. (2013). Examining factors of customer experience and their mediating role in retail banking sector: An empirical study. Global Management Review, 7(4), 30-39.

Cheng, F. F., Huang, Y. W., Yu, H. C., ve Wu, C. S. (2018). Mapping knowledge structure by keyword cooccurrence and social network analysis. Library Hi Tech, 36(4), 636-650.

Cook, G. (2014). Customer experience in the omni-channel world and the challenges and opportunities this presents. Journal of Direct, Data and Digital Marketing Practice, 15(4), 262-266.

DiJulius, J. R. (2008). What's The Secret? To Providing a World-Class Customer Experience. Wiley, USA.

Donthu, N., Kumar, S., ve Pattnaik, D. (2020). Forty-five years of journal of business research: a bibliometric analysis. Journal of Business Research, 109, 1-14.

Drotskie, A. (2009). Customer experience as the strategic differentiator in retail banking [PhD Thesis]. Stellenbosch: University of Stellenbosch.

Dubina, O., Us, Y. O., Pimonenko, T. V., ve Liulov, O. V. (2020). Customer loyalty to bank services: The bibliometric analysis. Virtual Economics, 3(3), 52-66.

Esen, F. S. (2020). Dijital Bankacılık Kullanımına Teknoloji Kabulü Temelli Bir Yaklaşım. Bilişim Teknolojileri Dergisi, 13(4), 401-410.

Fernandes, T., ve Pinto, T. (2019). Relationship quality determinants and outcomes in retail banking services: The role of customer experience. Journal of Retailing and Consumer Services, 50, 30-41.

Ferreira, H., ve Teixeira, A. A. C. (2013). "Welcome to the experience economy": Assessing the influence of customer experience literature through bibliometric analysis. Working Papers (FEP) - Universidade do Porto, 481, 1-28.

Garg, R., Rahman, Z., Qureshi, M. N., ve Kumar, I. (2012). Identifying and ranking critical success factors of customer experience in banks: An analytic hierarchy process (AHP) approach. Journal of Modelling in Management, 7(2), 201-220.

Garg, R., Rahman, Z., ve Qureshi, M. N. (2014). Measuring customer experience in banks: Scale development and validation. Journal of Modelling in Management, 9(1), 87-117.

Gentile, C., Spiller, N., ve Noci, G. (2007). How to sustain the customer experience: An overview of experience components that co-create value with the customer European Management Journal, 25(5), 395-410.

Gupta, R., Gupta, B. M., ve Kumar, A. (2017). Mobile banking: A scientometric assessment of global publications output during 2007-16. International Journal of Information Dissemination and Technology, 7(2), 128-134.

Handro, P.O. (2017). Customer experience and retail banking trends. Annals of "Constantin Brancusi" University of Targu-Jiu. Economy Series, Special Issue, 1, 128-134.

Handro, P.O. (2018). The role of customer experience in retail banking and the rise of fintechs. Annals of "Constantin Brancusi" University of Targu-Jiu. Economy Series, 1, 175-185.

Heshmati, E., Saeednia, H., ve Badizadeh, A. (2019). Designing a customer-experience-management model for the banking-services sector. Journal of Islamic Marketing, 10(3), 790-810.

Hirschman, E. C., ve Holbrook, M. B. (1982). Hedonic consumption: Emerging concepts, methods and propositions. Journal of Marketing, 46(3), 92-101.

Holbrook, M. B. (2000). The millennial consumer in the texts of our times: Experience and entertainment. Journal of Macromarketing, 20(2), 178-192. 


\section{G. Alkaç Özdemir - M. H. Altıntaş 13/2 (2021) 1856-1871}

Holbrook, M. B., ve Hirschman, E. C. (1982). The experiential aspects of consumption: Consumer fantasies, feelings, and fun. Journal of Consumer Research, 9(2), 132-140.

Homburg, C., Jozić, D., ve Kuehnl, C. (2017). Customer experience management: toward implementing an evolving marketing concept. Journal of the Academy of Marketing Science, 45(3), 377-401.

Hsu, H. Y., ve Tsou, H.-T. (2011). Understanding customer experiences in online blog environments. International Journal of Information Management, 31(6), 510-523.

Keiningham, T., Aksoy, L., Bruce, H. L., Cadet, F., Clennell, N., Hodgkinson, I. R., ve Kearney, T. (2020). Customer experience driven business model innovation. Journal of Business Research, 116, 431-440.

Klaus, P., Gorgoglione, M., Buonamassa, D., Panniello, U., ve Nguyen, B. (2013). Are you providing the "right" customer experience? The case of Banca Popolare di Bari. International Journal of Bank Marketing, 31(7), 506-528.

Klaus, P., ve Maklan, S. (2012). EXQ: A multiple-item scale for assessing service experience. Journal of Service Management, 23(1), 5-33.

Klaus, P., ve Maklan, S. (2013). Towards a better measure of customer experience. International Journal of Market Research, 55(2), 227-246.

Komulainen, H., ve Makkonen, H. (2018). Customer experience in omni-channel banking services. Journal of Financial Services Marketing, 23(3), 190-199.

Kraus, S., Li, H., Kang, Q., Westhead, P., ve Tiberius, V. (2020). The sharing economy: A bibliometric analysis of the state-of-the-art. International Journal of Entrepreneurial Behavior and Research, 26(8), 1769-1786.

Kumar, P. (2020). Measuring the emotional dimensions of retail banking experience in Non-Metro cities. Abhigyan, 37(4), 39-49.

Kuppelwieser, V. G., ve Klaus, P. (2021). Measuring customer experience quality: The EXQ scale revisited. Journal of Business Research, 126, 624-633.

Lee, H., Lee, K. K., ve Choi, J. (2018). A structural model for unity of experience: Connecting user experience, customer experience, and brand experience. Journal of Usability Studies, 14(1), 8-34.

Lemon, K. N., ve Verhoef, P. C. (2016). Understanding customer experience throughout the customer journey. Journal of Marketing, 80(6), 69-96.

Liu, L., ve Mei, S. (2016). Visualizing the GVC research: a co-occurrence network based bibliometric analysis. Scientometrics, 109(2), 953-977.

Makudza, F. (2020). Augmenting customer loyalty through customer experience management in the banking industry. Journal of Asian Business and Economic Studies, 2515-964X, 1-13.

Marangoz, M., ve Erboy, N. (2020). Bütünleşik Kanal Deneyimini Etkileyen Faktörlerin AHP Yöntemi ile Belirlenmesi: Bankacılık Sektörüne Yönelik Bir Çalışma. İşletme Araştırmaları Dergisi, 12(2), 1801-1819.

Mbama, C. I., Ezepue, P., Alboul, L., ve Beer, M. (2018). Digital banking, customer experience and financial performance: UK bank managers' perceptions. Journal of Research in Interactive Marketing, 12(4), 432-451.

Mbama, C. I., ve Ezepue, P. O. (2018). Digital banking, customer experience and bank financial performance: UK customers' perceptions. International Journal of Bank Marketing, 36(2), 230-255.

Medyawati, H., Christiyanti, M., ve Yunanto, M. (2011). E-banking adoption analysis using technology acceptance model (TAM): Empirical study of bank customers in Bekasi city. International Conference of Innovation Management and Service, 14, 91-95.

Meyer, C., ve Schwager, A. (2007). Understanding customer experience. Harvard Business Review, 85(2), 1-11.

Molinillo, S., Navarro-García, A., Anaya-Sánchez, R., ve Japutra, A. (2020). The impact of affective and cognitive app experiences on loyalty towards retailers. Journal of Retailing and Consumer Services, 54, 101948. 


\section{G. Alkaç Özdemir - M. H. Altıntaş 13/2 (2021) 1856-1871}

Nambisan, S., ve Baron, R. A. (2009). Virtual customer environments: Testing a model of voluntary participation in value co-creation activities. Journal of Product Innovation Management, 26(4), 388-406.

Nicolas, C., Valenzuela-Fernández, L., ve Merigó, J. M. (2020). Research trends of marketing: A bibliometric study 1990-2017. Journal of Promotion Management, 26(5), 674-703.

Oliver, R. L. (1980). A cognitive model of the antecedents and consequences of satisfaction decisions. Journal of Marketing Research, 17(4), 460-469.

Özdemir, E. (2016). Teknolojik Ürün ve Hizmet Pazarlaması, 2. Baskı, Bursa, Ekin Yayınevi.

Özturkcan Aykaç, S., ve de Kervenoael, R. (2008). Türkiye'de e-Bankacılık: Tüketici Deneyimleri. 13. Ulusal Pazarlama Kongresi, Kapadokya, 25-29 Ekim 2008, Türkiye, 1-18.

Paçan Özcan, H., Sabah Çelik, Ş., ve Özer, A. (2019). Bireysel müşterilerin mobil bankacılık kullanım niyetini etkileyen faktörler, Çankırı Karatekin Üniversitesi İktisadi ve İdari Bilimler Fakültesi Dergisi, 9(2), 475-506.

Palmer, A. (2010). Customer experience management: A critical review of an emerging idea. Journal of Services Marketing, 24(3), 196-208.

Pandey, S., ve Chawla, D. (2018). Online customer experience (OCE) in clothing e-retail: Exploring OCE dimensions and their impact on satisfaction and loyalty - Does gender matter? International Journal of Retail and Distribution Management, 46(3), 323-346.

Parasuraman, A., Zeithaml, V.A., ve Berry, L.L. (1988). SERVQUAL: A multiple-item scale for measuring consumer perceptions of service quality. Journal of Retailing, 64(1), 12-40.

Pekovic, S., ve Rolland, S. (2020). Recipes for achieving customer loyalty: A qualitative comparative analysis of the dimensions of customer experience. Journal of Retailing and Consumer Services, 56, 102171.

Pine, I.B.J., ve Gilmore, J. H. (1998). Welcome to the experience economy. Harvard Business Review, 76(4), 97105.

Piotrowicz, W., ve Cuthbertson, R. (2014). Introduction to the special issue information technology in retail: Toward omnichannel retailing. International Journal of Electronic Commerce, 18(4), 5-16.

Prahalad, C. K., ve Ramaswamy, V. (2004). Co-creation experiences: The next practice in value creation. Journal of Interactive Marketing, 18(3), 5-14.

Preciado-Ortiz, C. L., Gilsanz López, A., ve Vargas-Barraza, J. A. (2018). Mobile banking adoption: A bibliometric analysis. Revista de Dirección y Administración de Empresas. Número 25, Diciembre 2018, 1831.

Qiu, J. P., Dong, K., ve Yu, H. Q. (2014). Comparative study on structure and correlation among author cooccurrence networks in bibliometrics. Scientometrics, 101(2), 1345-1360.

Rather, R. A. (2020). Customer experience and engagement in tourism destinations: The experiential marketing perspective. Journal of Travel and Tourism Marketing, 37(1), 15-32.

Rose, S., Clark, M., Samouel, P., ve Hair, N. (2012). Online customer experience in e-retailing: An empirical model of antecedents and outcomes. Journal of Retailing, 88(2), 308-322.

Same, S., ve Larimo, J. (2012). Marketing theory: Experience marketing and experiential marketing. The 7 th International Scientific Conference "Business and Management 2012". Selected Papers, 480-487.

Sarma, P., ve Roy, A. (2020). A Scientometric analysis of literature on Green Banking (1995-March 2019). Journal of Sustainable Finance \& Investment, 11(2), 143-162.

Sayed, G., ve Sayed, N. S. (2020). Customer experience with digital banking-A comparative study of private and public sector banks. Productivity, 61(1), 19-33.

Schmitt, B. (1999). Experiential marketing. Journal of Marketing Management, 15(1-3), 53-67.

Sedighi, M. (2016). Application of word co-occurrence analysis method in mapping of the scientific fields (case study: The field of Informetrics). Library Review, 65(1/2), 52-64. 


\section{G. Alkaç Özdemir - M. H. Altıntaş 13/2 (2021) 1856-1871}

Shah, S. H. H., Lei, S., Noor, S., ve Anjum, A. (2020). Research synthesis and new directions of prosumption: A bibliometric analysis. International Journal of Information and Management Sciences, 31(1), 79-98.

Sharma, M., ve Chaubey, D. S. (2014). An empirical study of customer experience and its relationship with customer satisfaction towards the services of banking sector. Journal of Marketing and Communication, 9(3), 18-27.

Shaw, C. (2005). Revolutionize Your Customer Experience. UK, Palgrave Macmillan.

Shaw, C. (2007). The DNA of Customer Experience: How Emotions Drive Value. UK, Palgrave Macmillan.

Shaw, C., ve Ivens, J. (2002). Building Great Customer Experiences. UK, Palgrave Macmillan.

Shin, J. W. (2021). Mediating effect of satisfaction in the relationship between customer experience and intention to reuse digital banks in Korea. Social Behavior and Personality: An International Journal, 49(2), 118.

Silva, J. H. O., Mendes, G. H. S., Cauchick-Miguel, P. A., ve Amorim, M. (2020). Customer experience literature analysis based on bibliometry. In International Conference on Exploring Services Science, Springer, Cham., 3-20.

Sindhu, P., ve Bharti, K. (2020). Mapping customer experience: A taxonomical study using bibliometric visualization. VINE Journal of Information and Knowledge Management Systems, 2059-5891.

Siqueira, J. R., Ter Horst, E., Molina, G., Losada, M., ve Mateus, M. A. (2020). A Bayesian examination of the relationship of internal and external touchpoints in the customer experience process across various service environments. Journal of Retailing and Consumer Services, 53, 102009.

Srivastava, M., ve Kaul, D. (2014). Social interaction, convenience and customer satisfaction: The mediating effect of customer experience. Journal of Retailing and Consumer Services, 21(6), 1028-1037.

Štavljanin, V., ve Pantović, V. (2017). Online customer experience: Implications for digital banking. Bankarstvo, $46(2), 100-129$.

Taqi, M., Gurkaynak, N., ve Gencer, M. (2019). Marketing concept evolution: A bibliometrics co-occurrence analysis. Marketing and Management of Innovations, 2, 185-197.

Tisch, J. M., ve Weber, K. (2007). Chocolates on The Pillow Aren't Enough: Reinventing the Customer Experience. Hoboken, New Jersey, John Wiley and Sons.

Van Eck, N. J., Waltman, L., Dekker, R., ve Berg, J. van den. (2010). A comparison of two techniques for bibliometric mapping: Multidimensional scaling and VOS. Journal of the American Society for Information Science and Technology, 61(12), 2405-2416.

Verhoef, P. C., Kannan, P. K., ve Inman, J. J. (2015). From multi-channel retailing to omni-channel retailing: Introduction to the special issue on multi-channel retailing. Journal of Retailing, 91(2), 174-181.

Verhoef, P. C., Lemon, K. N., Parasuraman, A., Roggeveen, A., Tsiros, M., ve Schlesinger, L. A. (2009). Customer experience creation: Determinants, dynamics and management strategies. Journal of Retailing, 85(1), 31-41.

Von Saucken, C., Schröer, B., Kain, A., ve Lindemann, U. (2012). Customer experience interaction model. In DS 70: Proceedings of DESIGN 2012, the 12th International Design Conference, Dubrovnik, Croatia, 1387-1396.

Wallace, E., Buil, I., ve de Chernatony, L. (2013). Brand orientation and brand values in retail banking. Journal of Marketing Management, 29(9-10), 1007-1029.

Zeithaml, V. A. (1988). Consumer perceptions of price, quality, and value: A means-end model and synthesis of evidence. Journal of Marketing, 52(3), 2-22. 